\title{
Yoruba-Irish Literature: Intersection in the Language of Supernatural in Yeats and Soyinka
}

\begin{abstract}
The present paper aims at showing the intersection that Irish and Nigerian (especially the Yoruba) literatures share, particularly in the construction of the idea of supernaturalism, which is clearly exemplified in two of their most important works. No previous mention has ever been made of the convergence and divergence in the construction of the supernatural worlds in Yeats and Soyinka works, which are perfect metaphor for the two cultures representing Irish and African worlds. Using a descriptive textual analysis method textual evidence underpinning ideologies and narratives of the supernaturalism in these two worldviews are analysed. The paper shows, through the analyses of the language construing the idea of supernaturalism in Yeats' Countess Cathleen (1892) and Soyinka's Death and the King's Horseman (1976), not only the similarities and dissimilarities in how Irish and Yoruba cultures conceptualise their worlds of supernaturalism but also how such a belief system is negotiated and operationalised in the real world.
\end{abstract}

Keywords: Yeats ad Soyinka, Irish-Yoruba literature, literary intersection, Countless Cathleen, Death and the King's Horseman, supernaturalism, death and life.

\section{Introduction}

The idea to do a comparative analysis on the concept of supernaturalism in the duo works of Soyinka's Death and the King's Horseman (1975) and Yeats' Countess Cathleen (1892) is informed by my striking contact with Irish supernaturalism during my postgraduate days. According to the imperial literary canon which I read during my days in African universities, the two works belong to different cultural backgrounds. However, a careful reading of many works emanating from these two different cultures shows a rich ground of meeting point for different belief systems, such that one could suggest they may have shared histories. One of such belief systems is the similarities and dissimilarities found in the creation and representation of the supernatural world in their literary works, most notably those of Yeats and Soyinka. Among numerous textual evidences, elements of supernatural such as the belief that divine beings and phenomena could act as a deliberate intervention in human affairs and matters, are clearly present in both works. Also, supernatural associates representing death, eternity, soul, myth, afterlife, miracle, and the possibility of an 
intervention of the supernatural forces onto human scheme of things are not only well explored in the works, but also operationalised as an important factor shaping the people's daily choices in these literatures.

First, in Death and the King's Horseman (1975), the notion of death and soul is explored within the context of African world. Death is not a final end but a medium giving a life to a soul. In other words, soul is in itself a being, a life that can be transformed by death, which shows a clear relationship between soul and death. This explains the inevitability of the King's horseman to transform his life into a soul which will in turn allow him to perform his eternal duty of riding the horse to his eternal home. It thus suggests that death is responsible for isolating the soul from all the daily physical architectures that enclose it. So, death is not a means to an end but an end to a means. For instance, in Yeats' Countess Cathleen (1892), soul is seen worth much more than the human body or flesh. The human body often seeks to suppress the soul, yet only the soul will journey to eternal home. Hence, Yeats shows that the battle line for soul-winning is drawn between Catholicism and the Irish creed, while Soyinka shows that of a battle between the newly imposed Western Christian religion (of which Catholicism was at a forefront in the Eastern Nigeria, Protestant in the Southern Nigeria, and Islam in the Northern Nigeria) and the Yoruba creed.

According to Yeats and Soyinka, the new religion (i.e. the Catholicism in Ireland, and all the different but competing denominations in Nigeria) and the traditional creed sides with the supernatural forces, which they do using different methods. As Yeats shows, the medium with which the Merchants conducted the soul-winning task brings about a success in which more than expected number of souls is won. Also, the inability of Cathleen's spiritual foresight to prevent the steal is influential to the outcome of the play. Furthermore, the ideas of the timelessness of soul and afterlife are also used as crucial narrative techniques in both works. While Elesin Oba will happily ride home the King's horse after death, Cathleen's soul will be well received in heaven because of her good intentions.

At the center of the two plays are affinity between life and death, body and soul, mortality and immortality of body and soul, human sacrifice, death as a cultural and/or religious duty, the interlink of human world with the supernatural world, the belief in supremacy of the supernatural world, among many other themes. It can thus be argued that if these two texts of different backgrounds can arrive at a point with many similar/same ideas, then it goes to say that this intersection should be further studied, identifying shared cultural properties and ideologies as they may influence their supernatural worldviews, and everyday lives. As there has never been any mention of this link between these two cultures, the present study aims to open up a channel of discussion in this direction.

\section{Supernaturalism: A Thought}

According to Pandian (2002:3), supernaturalism is the belief in the existence of non-natural beings and powers, is constituted in myth and ritual, which, as vehicle for achieving coherence, meaning, and transcendence, are ultimately rooted in mytholiminal rationality. Mytholiminal rationality is 
a modality or aspect of human rationality that is involved on the one hand with the production of symbolic coherence (myth) and on the other with the production of transcendence (liminality) (cf. Pandian 2002: 3).

I share the definition of Pandian but reject his idea of stripping supernaturalism from the garment of religion. Supernaturalism works in tandem with every cultural system (Clifford, 1973). Soyinka and Yeats confirm this phenomenon in how they represent realities in their different but similar cultural worlds. For instance, Soyinka situates his supernatural play within the African world, using the medium of the Yoruba mythology while Yeats does the same by contrasting the Irish supernatural belief system with that of the catholic Christian's system which is in competition with the former. According to the two literary works under review, although they have the same substance and serve the same function, the workings of belief systems, especially those elements concerning its religion and mythology, which underpin supernaturalism, differ from one culture to another.

\section{Preliminary analyses and supernatural elements}

Different elements of supernaturalism permeate these two works at hand. It is outside what is held as natural law and observable world for soul to be article for sales. Soul-winning is arguably one of the tenets of Christian mission which Yeats and Soyinka clearly engage with. One important textual evidence concerns the decision of Cathleen to sell out her soul, a decision which arises as a result of a lack of material resources that develops from the loot of her treasury. Cathleen's treasury has been looted in a mysterious way and would therefore sell out her soul in order to survive. Yeats intends to clearly show the connection between our physical world and the world beyond, and that actions and choices in either world certainly impact on events and order of things in the other world. This argument is further shown by the spiritual-laden interaction between Aleel and the Angel, the miraculous appearance of the three Merchants who would later invite Spirits in the same way, and Cathleen's trance. In a very similar functional purpose, Cathleen's trance is the same as that of Elesin in Soyinka's Death and the King Horseman.

Soyinka and Yeats construe the phenomenon of the survival and transition of soul through a fierce contest between two forces. Unlike Soyinka, Yeats' contest is clearly between Catholicism and operationalisation of the traditional Irish belief system of supernaturalism. According to the work, Countess Cathleen, Aleel, Oona, and Mary are devotees of the former faith, while Shemus, Teig, and the hungry peasants are followers of latter faith. According to Mary, the followers of the traditional Irish belief system, that is, Shemus, Teig, and the hungry peasants follow the leadership of 'demons.' Mary also describes the three Merchants, who have brought enough food and drinks to the hungry land, as followers of demons. In Soyinka's work, Mary is a perfect equivalent of the Officer Mr Pilking who accuses Elesin as a follower of barbaric Yoruba traditional belief system. Both Countess Cathleen's camp (of the Catholicism) and the Merchants' Camp (of the traditional Irish system) have the same primary mission of 'winning' souls onto their gods/vineyards. As Yeats argues, the great famine caused many Irish believers to backslide, selling up their souls to 
the Merchants in return for food and drink, which amounts to some sort of 'salvation' from physical death. The backsliders could not trust the pathway to eternal salvation being promised by the Catholicism, which is further complicated by the famine.

Soyinka does create a similar supernatural world as well. Elesin's delayed death is forced through by Olohun-Iyo's invocation. On seeing the corpse of his son, Olohun-Iyo, who is Elesin's father, facilitates the death of his son through invocation. To Olohun-Iyo, doing so is an highly rewarding soul-winning missionary service. The survival of the soul of the King in the eternal world completely rests upon the death and transition of the Elesin's soul to meet up with the King's. Olohun-Iyo's invocation results into a supernatural surge.

Elesin's decision to happily die and save the soul of his master is against the belief system of the newly introduced Christian religion which the colonial government represents. Hence, it is a criminal offence to deliberately take one's life. Amusa, an officer of the colonial government, is one of those charged with reporting such crimes, but the egungun occultic power would influence Amusa's decision not to report Elesin's intention to die. In the African world, death can be a duty to be performed as is Elesin's duty to die and meet up with his master. Elesin's death is a call to a cultural duty, failure of which promises a disastrous and catastrophic future for the people of his community. As with Yeats, the relationship between death and soul is the central idea explored in Soyinka's Death and the King's Horseman (1976). As with a contest between Catholicism and Irish belief system in Yeats', so is a contest between Christianity and the Yoruba belief system in which both systems are exemplified by Mr Pilking, the colonial district officer and his wife Jane and Elesin, the king's horseman.

The imprisonment of Elesin, which is to prevent him from performing his duty of a call to die, could only bring more deaths as Olunde, the son of the incapacitated King's Horseman, felt a sense of urgency to avert a disastrous future for his people '...with his life.' (Soyinka 1976). Olunde performed the duty on behalf of Elesin, saving the souls of the king and that of his people who would face disastrous future should the soul of the king continue to wander endlessly in the afterlife. In other words, Olunde does not only carry out the timely duty of his family lineage but also offers a much-needed sacrifice for his entire community. Although Soyinka states that $\mathrm{Mr}$ Pilkings' resistance should not be solely interpreted as a clash between the old values and the new values, or a clash between the western methods and African traditions (Soyinka 1976), the play clearly compares with Yeats' themes of the relationship between death and soul and of a similar supernatural architecture.

\section{Textual Analyses: construing the supernatural worlds}

To some varying degree, both playwrights share some historical background in that they both belong to societies that have been subjected to forceful colonialism. Resistance to the imposition of a new order has been established. Conscious cultural revivalism was, and still, is ongoing, and is evident in the literary productions. While Irish literary works have achieved considerable success, African literature has appeared imprisoned infinitely. Yeats recalls the frightened Irish history of 
the Great famine, while Soyinka recalls how colonial's intervention in the cultural and religious life of the people they are forcibly governing resulted into more disastrous endings. Although set in the historical famine Ireland, no better background than the Great famine of the 17th century could have provided better surreal human conditions where choices pertaining to religious live are not only critical but also representative of the people's worldviews, sensibilities and belief systems. Like Yeats, Soyinka also documents important moments in the historical struggle for cultural independence by his people. According to Soyinka, the material of Death and the King Horseman (1976) was from 1946 actual event. The playwright writes: "In 1946, in the ancient Yoruba city of Nigeria, a well meaning District Officer Simon Pilkings intervenes to prevent the ritual suicide of the Yoruba chief, Elesin- a sacrificial suicide demanded by the death of the King. There follow drastic repercussions in both indigenous and colonial communities" (Soyinka 1976).

Just as Christ's sacrifice on the cross of Calvary for the sinful souls of the human world, it is right to say that both Cathleen and Olunde defy all odds, and offer their lives to death in exchange for the salvation of the souls of their communities. Cathleen and Olunde represent many Irish and Yoruba who conceptualise death as a form of transition, and as a cultural duty to be performed in a timely manner when necessitated. According to Cathleen, the famine has forced almost all the peasants into 'sins', which involves trading their souls for material things in order to survive. As it is evident in the excerpt below, Cathleen's sense of duty compels her to not only trade her expensive soul to redeem others but also to secure permanent salvation for the people on earth.

CATHLEEN.

FIRST MERCHANT

CATHLEEN
I come to barter a soul for a great price

The people starve, therefore the people go

Thronging to you, I hear a cry come from them

And it is in my ears by night and day,

And I would have five hundred thousands crowns

That I may feed them till the dearth go by.

There is more:

The souls that you have bought must be set free. I offer my own soul.

Five hundred thousand crowns; we give the price, The gold is here; the souls even while you speak. Have slipped out of our bond, because your face Has shed a light on them and filled their hearts But you must sign, for we omit no form In buying a soul like yours.

Take up the money, and now come with me; When we are far from this polluted place I will give everybody money enough. (half rising) Lay all the bags of money in a heap 
And when I am gone, old Oona, share them out

To every man and woman; judge and give

According to their needs, Elesin and his son, Olunde give up their lives for the salvation of others, to avert disastrous ending. Mr Pilkings' human knowledge and power are rendered useless in the execution of fate predestined by the gods. It is a mandatory cultural duty for the King's horseman, Elesin to die and accompany the soul of the King as they ascend to the ancestral world. This ascension will be aided by a horse, and a dog of which the former is a vehicle, and the latter a pathtracker. The dog tracks the path for the horse to follow. The horse is Elesin on whom the king will ride to the ancestral home. The consequence(s) of the failure of Elesin to die and therefore prevent the king from reaching home is/are undoubtedly disastrous and calamitous, not only for Elesin but also for the entire community. To avert this disastrous future, Olunde, the son of the incapacitated Elesin Oba, overtakes human error by performing the duty on behalf of his father who has been taken custody by the colonial government since he publicly declared his intention to die. Olunde avoids curse that could have been placed upon his family lineage, and that of the deadly future of his community, and consequently inspires his father's ultimate death.

\section{ELESIN. I cannot approach. Take off the cloth. I shall speak my message from heart to heart of silence. \\ IYALOJA (moves forward and removes the covering) Your courier Elesin, cast your eyes on the favoured companion of the King. (Rolled up in the mat, his head and feet showing at either end is the body of OLUNDE) There lies the honour of your household and of our race Because he could not bear to let honour fly out of doors, he stopped it with his life. The son has proved the father. Elesin, and there is nothing left in your mouth to gnash but infant gums.}

Thus, heroic honour may be appropriate for the larger-than-life Countess Cathleen and Olunde. Meanwhile man has deprived Elesin of his honour. This explains the African belief that man can hamper, delay and deprive mortal's success as it may be admissible in the supernatural world.

Unlike Yeats, Soyinka shows how the human world feels the resultant effects of the interplay of the supernatural and human worlds. Mr Pilkings' show of human knowledge in matters of the supernatural world is strongly frowned at in the supernatural world. Such arrogance of human error in matters of the supernatural can bring about significant unending human pains and sufferings, which remain valid belief in today's Africans' worldviews. Rather than the sole Elesin's soul, Pilkings' interference does not only double the casualties but also affirms the inevitability of fate. It also interprets that man, irrespective of age, expertise, knowledge and craft is an innocent 'child' in the affairs of man that are midwifed by the supernatural forces. The following conversation between Iyaloja and Pilkings further show the cost of human error in supernatural affairs. 
IYALOJA.

PILKINGS.

IYALOJA:
To prevent one death you will actually make other deaths?

Ah, great is the wisdom of the white race...

(in a tired voice): Was this what you wanted?

No child, it is what you brought to be, you who,

play with strangers' lives, who even usurp the vestments of our dead

yet believes that the stain of death will not cling to you. The gods

demanded only the old expired plantain but you cut down the

sap-laden shoot to feed your pride....

If there is human sacrifice, there must be afterlife, an imagined world where the heroes ascend. The interconnectivity of these worlds could not be explained by methodological processes. As it is evident, the duality of afterlife is presented by Soyinka and Yeats. The souls of heroic people like Countess Cathleen will ascend to the heaven, while those of the unspirited will ascend to Hell. Yeats' reference to the distinction of Hell and Heaven is a pun on the strict worldview on morality and immorality by the Catholicism. Such strict distinction does not exist in either the Irish or the Yoruba world, both of which compete with the western ideology of moral paradigm. In addition, the world of the ancestors where the soul of King is destined is an equivalent of Heaven, a resting home. But the King's soul could not journey to the Heaven on its own without the help of his aide the Horseman. In other words, the failure of the horseman to arrive may amount to the soul of the King 'hanging' in a place other than the Christian Heaven. In other words, if the Christian imagined world of Heaven is nothing but a resting home, then the Yoruba's idea of the world of the ancestor is an equivalent. Hence, Countess Cathleen, the King, Olunde, king's horse and the dog would arrive different at culturally-laden and built heavens, where God, angels, and good people are believed to dwell, while out-of-favour Elesin, Teig, Shemus, and the Merchants would arrive at Hell, at least according to Mary. However, it is surprising that Cathleen's admittance is only motivated by her altruism.

THE ANGEL.

The light beats down; the gates of pearl are wide.

And she is passing to the floor of peace,

And Mary of the seven times wounded heart

Has kissed her lips, and the long blessed hair

Has fallen on her face; The Light of Lights

Look always on the motive, not the deed,

The Shadow of Shadows on the deed alone.

On the other hand, the criteria for admittance into Soyinka's Yoruba perfect dwelling place is not measured by deed but by act; an accomplishment of duty, irrespective of human error or barriers. In a contemporary world, one would expect prerogative of mercy for Elesin but, according to the playwright, 'oh, how late it all is. His son will feast on the meat and throw him bones...' 
Furthermore, the two works present us with supernatural events and occurrences that shape the resolution of the plays. Like in the Christian world where it is believed that the challenges of life are better fought in the spiritual, Countess Cathleen's downfall is charted in the spiritual, just as Olunde interceded for his father, engaging in invocation which brings about the desired ultimate fate. Unlike Elesin, who does not have the means to prevent his people from enduring calamity should he fail to perform his duty, Cathleen does have more than enough wealth that would prevent the people from trading their souls for food.

\section{CATHLEEN}

My thanks to God, to Mary and the angels

That I have money in my treasury,

And can buy grain from those who have stored it up

To prosper on the hunger of the poor

But you've been far and know the signs of things

When will this yellow vapour no more hang

And creep about the fields, and this great heat

Vanish away, and grass show its green shoots?

Just as Pilking, Cathleen is a human agent that must be dealt with in order to win souls for the other camp. Hence the best way to deal with that is to capture her power, which is the wealth. This means that when she becomes poor, it will be difficult or almost impossible to attract souls to her camp. In other words, Cathleen's material resource has been a barrier to Merchants' ability to win more souls to their own camp. The Merchants' aim is to win all the human souls, using different strategies that include monopolizing materials which attract humans. Just like the contest between Pilking and Elesin, the following excerpt shows how the magical merchants plan to battle Cathleen in the spirit.

\section{FIRST MERCHANT. Although I bid you rob her treasury \\ I find you sitting drowsed and motionless, \\ And yet you understand that while it's full \\ She'll bid against us and so bribe the poor \\ That our great Master'll lack his merchandise. \\ You know that the she has brought into this house}

The attack is carried out spiritually, overpowering the physical presence of man that secures the treasury. Such is the similar overpowering of Pilking by the spiritual intervention of the gods through the invocation entered into by Olunde, together with the spiritual desire of the entire community. 
OONA

CATHLEEN

PORTER. (entering hurriedly)

Ochone! Ochone! The treasure room is broken in,

The door stands open, and the gold is gone

Ochone!

That my good mistress should lose all this money

Let those among you-not too old to ride--

Get horses and search all the country round,

I'll give a farm to him who finds the thieves.

(A man with keys at his girdle has come in while she

speaks. There is a general murmur of The Porter!

The porter!

Demons were here. I sat beside the door

In my stone niche, and two owls passed me by,

Whispering with human voices. By losing the treasury, Cathleen loses both her physical and spiritual power to contest comfortably in the contest for the souls of a people who have gone mad by the painful touch of famine. For artistic purposes, Yeats restores her spiritual consciousness, enabling her to realise that the attack is a signal to home call. In a further contest, Cathleen would seek the aid of her own spiritual superior.
CATHLEEN.
Ah, no, not that.
A sad resolve wakes in me. I have heard
A sound of wailing in unnumbered hovels,
And I must go down, down-I know not where-
Pray for all men and women mad from famine
Pray, you good neighbours.

(The PEASANTS all kneel. COUNTESS CATHLEEN ascends the steps to the door of the oratory, and turning round stands there motionless for a little, and then cries in a loud voice)

Mary, Queen of angels,

And all you clouds on clouds of saints, farewell!

The famine grows taller, and more people continue to trade souls with the 'demons' as Mary argues. But Countess Cathleen's strength has been significantly weakened, forcing her to trade her own soul in order to recollect enough money for the redemption of the souls of her people. She could have redeemed all the souls with the strong power of her wealth, but she has already lost the battle in the spiritual, a scenario that translates into the physical. As it will be shown, the Merchants, again, summon the spirits-dancers, who perform dance theatre. 
FIRST MERCHANT. I'll call them, and who'll dare to disobey?

Come, all you elemental populace

From Cruachan and Finbar's ancient house.

Come, break up the long dance under the hill,

Or if you lie in the hollows of the sea,

Leave lonely the long hoarding surges, leave

The cymbals of the waves to clash alone,

And shaking the sea-tangles from your hair

Gather about us.

(The SPIRITS gather under the arches)

SECOND MERCHANT. They come. Be still a while.

There is an equivalent of this spiritual presence on the physical world in Soyinka's Death and the King Horseman. For instance, Elesin is buried in invocation by the Praise Singer's chants which invites supernatural forces that eventually caused Elesin's ultimate death. The fact that this performance of duty happened in the presence of the opposition shows the interconnection of the physical and spiritual worlds. The surge for Elesin's death is beyond the control of Elesin himself! In a similar vein, the willingness and bravery of Olunde to overtake his father's death further shows the superiority of the supernatural world over the physical human mind. It can be argued that such bravery facilitates the presence of the unseen forces that midwife the ultimate Elesin's suicidal ritual. The significance of this lies in the interface of two worlds; the spiritually-inspired physical bravery of Olunde combines with the supernatural forces to forcibly intervene. According to the Praise- Singer, time and fate go hand in hand.

PRAISE-SINGER.

Elesin, we placed the reins of the world in your hands yet you watched it plunge over the edge of the bitter precipice. You sat with folded arms while evil strangers tilted the world from its course and crashed it beyond the edge of emptiness-you muttered, there is little that one man can do, you left us floundering in a blind future. Your heir has taken burden on himself. What the end will be, we are not gods to tell. But this young shoot has poured its sap into the parent stalk, and we know this is not the way of life. Our world is crumbling in the void of strangers, Elesin.

(ELESIN has stood rock still, his knuckles taut on the bars, his eyes glued to the body of his son. The stillness seizes and paralyses everyone, including PILKINGS who has turned to look. Suddenly, ELESIN flings one arm round his neck, once, and with the loop of the chain, strangles himself in a swift, decisive pull. The guards rush forward to stop him but they are only in time to let his body down. PILKINGS has leapt to the door at the same time and struggles with the lock...) 
According to the physical laws, certain questions such as what killed Elesin or what inspired his surge can be asked. However, no answer could be found in those physical laws, except in the supernatural world. In other words, one can trace his death to a number of factors which are primarily led by the invocation and the incantations of Oluhun-Iyo. His sacred words are highly spirited and possessed, causing the presence of Spirits as those of Merchants within the time and space of Elesin. In other words, Praise Singer's incantation and invocation do not only create the enabling spiritual atmospheric condition but also provide sufficient energies and vibes that outweigh those of the oppositions.

The relationships between body and soul, flesh and man, and self and soul are exemplified by the representations of Countess Cathleen, Elesin and Olunde. Man is a body made up of flesh with which soul interacts and links with the supernatural world. The souls of Elesin and Olunde connect the flesh with the supernatural world, moving beyond the physical world. Elsewhere, John Donne has argued in the poem Death, Be Not Proud (1610) 'one short sleepe past, we wake eternally. And death shall be no more; death, thou shall die.' According to Donne, only the flesh or body that can die, which thus means that death is a passage to eternity of soul.

The idea of death as an end to a means but not as a means to an end inspires Countess Cathleen and Olunde who sacrificially give up their bodies/flesh for the salvation of many other souls. Although Cathleen and Elesin suffered physical death, according to Yeats and Soyinka, their souls will not only find happiness in the afterlife but will also serve as a lesson to many in the physical world that the salvation of soul is more important than the glorification of the human flesh or body. As the excerpt below show, Cathleen's soul drifts into eternity among others souls; a journey which is confirmed by a supernatural representative, The Angel.

THE ANGEL.

The light beats down; the gates of pearl are wide.

And she is passing to the floor of peace,

And Mary of the seven times wounded heart

Has kissed her lips, and the long blessed hair

Has fallen on her face; The Light of Lights

Look always on the motive, not the deed,

The Shadow of Shadows on the deed alone.

(ALEEL releases the ANGEL and Kneels)

In Soyinka's work, the transition from the world of flesh and blood into the world beyond may not be journeyed with only the body and flesh. The King has passed away and the body/flesh is no longer important as it is not required to embark on the spiritual journey to his ancestral home. Iyaloja provides insight into the path:

IYALOJA.

They have slain the favourite horse of the king and slain his dog. They have borne them from pulse to pulse centre of the land receiving 
prayers for their king. But the rider has chosen to stay behind.

This soul journey links us up with the object of transaction by the merchants. We may further ask why the merchants trade not in body and flesh, but in souls?

FIRST MERCHANT. They have not sold all yet.

For there's a vaporous thing - that may be nothing,

But that's the buyer's risk-a second self,

They call immortal for a story's sake.

SHEMUS.

You come to buy our souls?

TIEG.

I'll barter mine.

CATHLEEN.

Why should we starve for what may be but nothing?

SHEMUS.

But there's a world to come.

And if there is,

I'd rather trust myself into the hands

That can pay money down than to the hands

That have but shaken famine from the bag.

The body, the flesh and the Self are all perishable goods but 'in a world to come' but only imperishable 'elemental forces' are habitable. The gap between body and soul is filled up by death, which is meant by 'one short sleepe'. The body sleeps but the soul never does. It interprets that only the Terminal End of A human body implies death; death of a man in flesh is not final. Both literary works insin-

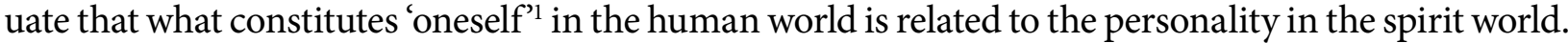

In fact, the Yoruba believes that earthly occupations are immanent not only to the flesh but also to the soul. It suggests that a fisherman is not only a fisherman here on the physical world but remains a fisherman in soul; even after his death in the world beyond. Therefore, Elesin Oba would carry on his occupation as King's Horseman, as well as Olohun Iyo, the Praise Singer.

PRAISE SINGER.

Are you sure there will be one like me on the other side? Far be it for me to belittle the dwellers of that place but, a man is either born to his art or he isn't. And I don't know for certain that you'll meet my father, so who is going to sing these deeds in accents that will pierce the deafness of the ancient ones. I have prepared my going-just tell me; Olohun-iyo, I need you on this journey and I shall be behind you.

Mysticism adorns the two supernatural works. There are three levels of spiritual systems that operate in the broad scope of the two works. In Countess Cathleen, Yeats contrasts the Christian spiritual system with the Irish supernatural beliefs. But to Soyinka, there is no need to juxtapose

1 The totality of what man stands for on earth. 
the Yoruba world of supernatural, so he deliberately did not draw from Catholicism or any other social spectrum to fully unfold the position of mysticism in the Yoruba world. Yeats employs Tieg and Shemus to $\mathrm{x}$-ray the Irish belief in mysticism. Tieg and Shemus remian committed to their customary belief, unmoved to the Christian ideas as exemplified by Mary, Aleel, Countess Cathleen, and so many others. Tieg and Shemus are engrossed in the Irish supernatural world such that they are always caught up in references to it.

TEIG.

In the bush beyond,

There are two birds---if you can call them birds--

I could not see them rightly for the leaves,

And I'm half certain they've a human face

They're looking at me.

What is the good of praying? Father says

The belief that personal communication or union with the divine is achieved through intuition, faith, ecstasy, or sudden insight rather than through rational thought is evident by Tieg and Shemus' communication with the unseen beings.

\section{SHEMUS.}

(at door)

Whatever you are that walk the woods at night,

So be it that you have not shouldered up

Out of a grave-for I'll have nothing human---

And have free hands, a friendly trick of speech,

I welcome you. Come, sit beside the fire.

Or you've a horse's tail to whip your flank,

Feathers instead of hair, that's but a straw,

Come, share what bread and meat is in the house,

And stretch your heels and warm them in the ashes.

And after that, let's share and share alike

And curse all men and women. Come in, come in.

What, is there no one there?

(Turning from door)

And yet they say

They are as common as the grass, and ride

Even upon the book in the priest's hand.

(TEIG lifts one arm slowly and points toward the door and begins moving backwards. SHEMUS turns, he also sees something and begins moving backward. MARY does the same. A man dressed as an Eastern merchant comes in carrying a small 
TEIG.

\section{SHEMUS}

TEIG.

SHEMUS. carpet. He unrolls it and sits cross-legged at one end of it. Another man dressed in the same way follows, and sits at the other end. This is done slowly and deliberately, when they are seated they take money out of embroidered purses at their girdles and begin arranging it on the carpet.

You speak to them

No, you

'Twas you that called them.

(coming nearer)

I'd make so bold, if you would pardon it,

To ask if there's a thing you'd have of us,

Although we are but poor people, if there is,

Why, if there is

In the Christian world, the interaction is done by medium of summon through prayer. Aleel uses this medium to summon the appearance of Angels to provide foresight and divination into the passage of Cathleen. This is followed by a trance in which Cathleen enters into a world beyond to interact with the other side of the world.

\title{
CATHLEEN
}

Ah, no, not that

A sad resolves wakes in me. I have heard

A sound of wailing in unnumbered hovels, And I must go down, down-I know not where---

Pray for all men and women mad from famine;

Pray, you good neighbours.

(The PEASANTS all kneel. COUNTESS CATHLEEN ascends the steps to the door of the oratory, and turning round stands there motionless for a little, and then cries in a loud voice)

\author{
Mary, Queen of angels, \\ And all you clouds on clouds of saints, farewell!
}

Here, Cathleen enters into a trance through invocation of the Christian spirits, which may be described as the Holy Spirit by the believers in Christian superstitions. 
(ALLEL kneels beside her, but does not seem to hear her words. The PEASANTS return. They carry the COUNTESS CATHLEEN and lay her upon the ground before OONA and ALEEL. She lies there as if deed)

Unlike Yeats, Soyinka's sole intention is just an exploration of the supernatural belief of the Yoruba, and how this belief outplays the human barriers in 1946. Pilkings, a well-meaning District Officer, had stood to prevent ritual suicide of Elesin but he was overpowered by supernatural force. This supernatural force projects Elesin into a trance in the very eyes of Pilkings and prison guards. It is this dazed state of body that forced out the soul of Elesin. He does not willfully lose himself in this state but is overwhelmed by the supernatural intervention. The incorruptibility of the space within which this interaction ensues barricades human interference from Pilkings, Jane, and the guards. It is the same state in which Cathleen professes her death before trading her soul in the human face. No human force can prevent her from trading her soul.

While spiritual arrogance is dealt with by Yeats, Soyinka's concern is purely recounting the usual interplay between immortal and mortal. Shemus, Tieg, and the peasants follow the spiritual leadership of the three Merchants, who 'must tramp the world,' because they 'travel for the Master of all merchants, ${ }^{3}$ Mary, Aleel, Oona, and Cathleen follow the Christian spiritual leadership of Holy Mary, who claims spiritual superiority over Shemus and Co. Cathleen condemns the other camp as a destroyer of the world, and destroyer of the peace of the world. But Shemus lashes back, claiming that the God of Mary and Cathleen have not done better in the affairs of man because He has only visited them with more than enough famine.

\section{CATHLEEN.}

SHEMUS.

\section{But there's a world to come.}

And if there is,

I'd rather trust myself into the hands

That can pay money down than to the hands

That have but shaken famine from the bag.

(He goes out right)

(lifting) There's money for a soul, sweet yellow money.

There's money for men's souls, good money, money."

The readers are able to interact with a number of experiences which are enriched by the presence of supernatural forces like the ghosts, demons, angles, spirits, etc. Shemus and Tieg clearly picture in our mind what we love to see but that which often could not be seen. Or what we love to hear but that which often do not hear. Or what we love to feel or experience but that which of-

2 Yeats, Williams Butler, Countess Cathleen, 1892.

3 Yeats, Williams Butler, Countess Cathleen, 1892. 
ten could not be felt or experienced. Shemus narrates one ironic nature of man and the desire for things of the supernatural world in the physical world.

\title{
SHEMUS.
}

\author{
I heard say \\ There's something that appears like a white bird, \\ A pigeon or a seagull or the like, \\ But if you hit it with a stone or a stick \\ It clangs as thought it had been made of brass; \\ And that if you dig down where it was scratching \\ You'll find a crock of gold
}

This looks like adventurous experiences that may not be created or experienced in a physical world. Soyinka supplements this supernatural desire with another sub-plot. The story of the Not-I' bird, and Elesin's moon tale are a chain of events that motivate the hearts of Elesin.

\section{ELESIN.}

$$
\begin{aligned}
& \text { The moon was my messenger and guide. When it reached a certain } \\
& \text { gateway in the sky, it touched that moment for which my whole } \\
& \text { life has been spent in blessings. Even I do not know the gateway } \\
& \text { I have stood here and scanned the sky for a glimpse of that door } \\
& \text { but, I cannot see it. Human eyes are useless for a this nature. But } \\
& \text { in the house of osugbo, those who keep watch through the spirit } \\
& \text { recognised the moment, they sent word to me through the voice } \\
& \text { of our sacred drums to prepare myself. I heard them and I shed all } \\
& \text { thoughts of earth. I began to follow the moon to the abode of gods. }
\end{aligned}
$$

The idea of the egungun ${ }^{4}$ and its paraphernalia is a sacred one, which is alien to the white, Mr. Pilkings.

AMUSA.

4 Ancestral masquarade
Mista Pirinkin, I beg you sir, what you think you do with that dress? It belong to dead cult, not for human being ... Mista Pirinkin, I beg you, take it off. Is not good for man like you to touch that cloth. Sir, it is a matter of death. How can man talk against death to person in uniform of death?...

Madam, I arrest the ring leaders who make trouble but me I no touch egungun. That egungun itself, I no touch. And I no abuse am. I arrest ring-leader but I treat egungun with respect. 
One element of the supernatural world in the literature that makes mythical tales not verifiable is the peopling of its world by ghosts, angels, demons, devils, spirits, fairies, and maybe, superman and super-inanimate. Yeats stuns the readers when he brings Angels down onto the earth, saving Aleel's energy of summoning. Another heaven on earth is the three Spirits-dancers who perform dance for the same spirited Merchants.

ALEEL.

Look no more on the half-closed gates of Hell,

But speak to me, whose mind is smitten of God,

That it may be no more with mortal things,

And tell of her who lies there.

(He seizes one of the angels.)

Till you speak. You shall not drift into eternity

The implications of the ability by a human, Aleel, to seize an Angel are infinite! A human hand puts an Angel in hostage, forcing a premonition. The Angel speaks in human tongue to Aleel before being set free.

THE ANGEL.

The light beats down; the gates of pearl are wide,

And she is passing to the floor of peace,

And Mary of the seven times wounded heart

Has kissed her lips, and the long blessed hair

Has fallen on her face; The Light of Lights

Look always on the motive, not the deed,

The Shadow of Shadows on the dead alone.

(ALEEL releases the ANGEL and kneels.)

The presence of such supernatural creatures is rather implied in Death and the King's Horseman (1976). This can only be worked out by a believer in the Yoruba religion. The King's corpse is a month's old, for which the unburied corpse, kept in a sacred place, is a toast of visits for spirits, Angelical beings, and all delegated creatures, among whom is Elesin Oba.

\section{Conclusion}

The present paper has provided some textual evidence showing the extent to which the idea of supernaturalism is presented in two different literary works that have never been explored comparatively. The paper also shows the different strategies with which this idea is construed, such that the belief systems in the two different cultural worlds of the Yoruba and the Irish are brought to the fore front. It is widely accepted that the idea of supernatural is present in all cultures, though it may be constructed in different ways. But in whatever forms they may be represented, some elements such as paranormal and occult ideas are always present. 
One central contribution of the paper is that the narrative and language of cultural beliefs of different cultures may overlap, which affirms the argument that supernaturalism is to some extent a matter of universals in world cultures and by extension literatures. In addition, the paper has shown that African literature, which has often been compared to Caribbean literature and African American literature for obvious historical reasons, can as well begin to look for interesting intersecting ideologies in European literature, especially in Irish literature. For instance, while Yeats draws on magical inputs, Soyinka draws on occult idea of egungun. In both works, we have interaction of man with the supernatural networks by a way of summoning the spirits and transition into trance, which is exemplified by the collapse of Cathleen and the process of Elesin's death. Also, the power of Countess Cathleen is stolen spiritually while Pilkings' barrier to Elesin's death is also removed spiritually and miraculously.

Summing up all of these anecdotes in both literary works, I argue that both works clearly intend to show that the supernatural is not only superior to the human world but also that a liner relationship exists between the two worlds. As the literary works show, these hypotheses are well presented and can be described as a paramount cultural ideology in both the Irish and Yoruba worlds. Although one may argue that though such ideology may not be clearly pronounced in the contemporary Irish realities as it is in the contemporary Yoruba realities, the extent of convergence and divergence still remains a grey area that has never been explored. While the present work has attempted at showing important cultural element from two traditions that are well apart, i.e. the idea of supernaturalism - how it works, its inhabitants, its relationship with man and the physical world, more research into this neglected intersection is required.

\section{References}

\section{Primary Texts}

Soyinka, Wole. 1975. Death and the King's Horseman. London: Methuen.

Yeats, W.B. 1908. Poems. London: T. Fisher Unwin.

\section{Secondary Sources}

Geertz, Clifford. 1973. The Interpretation of Cultures. New York: Free Press.

Harkness, Sara and Charles Super (eds.). 1996. Parents' Cultural Belief Systems. New York: Gildford Press.

Jeremy, Hawthorn. 1987. Unlocking the Text: Fundamental Issues in Literary Theory. London; Arnold.

Balogun, S. 2014. Death and suicide in African plays. Available from: https://www.amazon.com/ kindle/dp/B00M7H5UVI/ref.rdr_Kindle_eet_eos_detail (accessed 09 November 2017).

Brown, Terence. 1999. The Life of W. B. Yeats: A Critical Biography. Dublin: Gill \& Macmillan.

Forman G. Brown. 1925. Mr Yeats and the Supernatural. The Sewanee Review 33 (3): 323-330.

Gregory, Lady. 1970. Visions and Beliefs in the West of Ireland. Vale: Gerrands Cross. 
Kluckhom, Clyde and Alfred L. Kroeber. 1952. Culture: A Critical Review of Concepts and Definition, NY: Vintage Books.

Martin, Augustine. 2006. W. B. Yeats. London, England: Paperview-Irish Independent.

Pandian, Jacob. 2002. Supernaturalism in Human Life: A Discourse on Myth, Ritual and Religion, New Delhi; Vedams eBooks.

Ronald Schuchard. 2008. The Last Minstrels: Yeats and the Revival of the Bardic Arts. Oxford: OUP.

Schuchard, Ronald. "The Countess Cathleen and the Revival of the Bardic Arts." Web 12 Apr 2012. http://www.dolmetsch.com/024_Schuchard.pdf

Yeats, W.B. Crossways. The Collect Poems of W. B. Yeats. New York: Simon \& Schuster Inc., 7-26. 